\title{
Maritime, Oceans and Sustainability - A Way Forward
}

\author{
Cleopatra Doumbia-Henry ${ }^{1}$
}

Published online: 15 February 2016

(C) World Maritime University 2016

As President of the World Maritime University, it gives me great pleasure to contribute an editorial to this volume of the WMU Journal of Maritime Affairs.

This volume - the 15-again demonstrates the strength of the Journal and the role it has played since 2002 in providing a forum for the dissemination of important research on the wide array of topics that fall within the field of "maritime affairs".

In doing so, it also contributes to ensuring recognition that "maritime affairs" with its many facets and involving many different academic disciplines is now itself an increasingly important field for academic research and education. This is also linked to the mission of the World Maritime University (WMU) which brings together governments, industry actors and academics all engaged in different ways with the maritime world. In line with its aims of "serving the international maritime community by presenting fresh ideas and current thinking on subjects of topical interest, reporting on relevant research findings and addressing interrelationships between safety, environment protection and efficiency of maritime transport", Volume 15 will contain an exciting array of articles addressing contemporary issues.

These articles cover a range of subjects: the linkage between the structure of headings in operating and maintenance manuals on board ship and human error; the impact of larger capacity fleets on fuel efficiency and cost savings in light of the expansion of the Panama Canal; a programming model that optimizes in an integrated way the scheduling of handling and storage of containers at automated container terminals; barriers to energy efficiency in shipping and ways to address them; the effectiveness of classroom-based bridge resource management training on knowledge, attitudes, behaviour and performance of junior naval officers; a safety and risk management approach based on the Swiss cheese model of the characteristics of a hole; the perception and image of shipping; and a proposal for a model course to demonstrate and revalidate deck officers' competences by using simulation.

\section{Cleopatra Doumbia-Henry}

1 President, World Maritime University, Malmö, Sweden 
These articles in various ways all touch on the three dimensions of sustainable development - economic, social and environmental.

We are now at a very exciting juncture in the history and life of WMU. In April 2105, WMU moved to a new campus with facilities provided by the City of Malmo. This will better allow it to meet the needs of students and the wider oceans community who increasingly come to WMU to participate in cutting edge specialized professional workshops, seminars and international conferences. In 2015, in light of the wider United Nations commitment to address sustainable development including improving ocean governance, WMU was given an expanded mandate from the Council and Assembly of the International Maritime Organization (IMO). Today, WMU is increasingly recognized as the international post-graduate education and research institution that is a world centre of excellence in the field of maritime affairs. Its fundamental objective is to provide the international maritime community and in particular developing and emerging economy countries and the industry with a centre for maritime education, research and scholarship with a view to promoting the achievement globally, of the highest practicable standards in matters concerning maritime safety and security, efficiency of international shipping and the prevention and control of marine pollution including air pollution from ships and other marine- and ocean-related issues.

WMU now has the mandate not only to deal with the United Nations 2030 Agenda for Sustainable Development and its Sustainable Development Goals and Targets but also an explicit mandate on the Ocean Agenda. In 2015 and 2016, WMU is further integrating these goals into its education, training, capacity-building and research programmes.

It is against this background that I wish to take the opportunity to highlight a development that has and will continue to have significant implications for the maritime industry as a whole. This relates to the significance and importance of the decisions made by heads of states, governments and high representatives of 193 member States of the United Nations on 25 September 2015 when they adopted a set of bold new global goals concerning the 2030 Agenda for Sustainable Development and which comes into force on 1 January 2016. United Nations Secretary General, Ban $\mathrm{Ki}$ Moon, hailed this agenda as the "most inclusive development agenda the world has ever seen" and described these goals as "a universal, integrated and transformative vision for a better world". The new framework, "Transforming Our World: the 2030 Agenda for Sustainable Development", is composed of 17 goals and 169 targets to eradicate poverty, fight inequality and tackle climate change over the next 15 years.

A 15-year timeline has been set to achieve these ambitious goals and targets. The goals cut across the three pillars of sustainability: economic, social and environmental. Of specific relevance to the maritime industry and the ocean community are goals 7 , 13, 14 and 17. Goal 7 deals with ensuring access to affordable, reliable, sustainable and modern energy for all. Goal 13 calls for urgent action to be taken to combat climate change and its impacts. Goal 14 requires the conservation and sustainable use of the oceans, seas and marine resources for sustainable development. This is the first time that a goal has been dedicated to the Ocean, which represents $71 \%$ of our planet. Goal 14 is a timely call for action, a call for ocean governance. This goal calls on the international community to prevent and significantly reduce marine pollution by 2025 . It is a target to be achieved in 10 years - and earlier than the 15-year target date for all goals. In addition, by 2020, therefore in 5 years, countries must have effectively 
regulated fisheries and put an end to overfishing. Goal 17 calls for strengthening the means of implementation and revitalizing the global partnership for sustainable development.

In his opening address to the General Assembly before the adoption of the Agenda, the UN Secretary General referred to the need to engage all actors and specially stated that "[w]e must listen to scientists and academia".

This is the opportunity for WMU to ensure that it continues to make a contribution through targeted and innovative research to enable policy makers to use research findings and advice to guide the policy decisions they are making or need to make. Academics, through education and research, have a responsibility in helping to implement these goals. The WMU Journal plays an important role in helping to disseminate innovative research that will help address knowledge gaps and support policy decisions that need to be made.

As a result of its broader mandate and in order to better serve these sustainable development goals, I am pleased to note that WMU will be offering two new MSc specializations from 2016: Maritime Energy Management and Ocean Sustainability, Governance \& Management. This ensures that WMU will be in a position to contribute in a substantive way to building capacity for the implementation of the goals referred to above. The WMU will also be expanding its research agenda and intends to establish a WMU Ocean Policy and Science Research Institute. WMU's curriculum for 2017 will also include a subject on Maritime Policy dedicated to improving expertise on the implementation of the conventions adopted by the IMO and other relevant UN agencies.

I also consider it important to draw attention to the social dimension of the SDGs as it relates to the maritime and fishing industry. That the Maritime Labour Convention, 2006 (MLC, 2006), and the Work in Fishing Convention, 2007 (No.188), adopted by the International Labour Organization (ILO), contain the minimum standards required for compliance with the social dimension in the maritime and fishing sectors. The MLC, 2006, is the bill of rights for the world's maritime workers and a framework for creating a level playing field for Governments and shipowners. For the world's fishers, their bill of rights is contained in the Work in Fishing Convention, 2007. In addition, ensuring wider and better implementation of the ILO's Seafarers' Identity Documents (Revised) Convention, 2003, which complements the IMO's Convention on Facilitation of International Maritime Traffic, is a source of major concern to shipowners and seafarers, with an international meeting scheduled in early 2016 to consider significant amendments. Another international meeting will consider amendments to the MLC, 2006, to deal with a very difficult issue of workplace bullying and harassment on board ship and also consider changes to the Convention that clarify the question of contracts and the payment of wages to seafarers who are victims of piracy. While the MLC, 2006 , is continuing to attract ratifications ( 70 to date), it is effective flag State inspection, port State control and monitoring by the ILO supervisory bodies that will provide the indicators for measuring the effectiveness of the social dimension of goal 14 of the SDGs.

I also wish to highlight the humanitarian, political, social and economic challenges of the current dramatic migrant crisis with desperate people using unseaworthy ships and unscrupulous and criminal human traffickers to reach Europe, creating one of the most important migrant crises of our times. This crisis has important implications for 
the shipping industry including with respect of search and rescue and the IMO's Search and Rescue Convention. I am pleased to announce that the WMU will host, on 26 and 27 April 2016, a major Conference on Migrants at Sea, taking into account the UN Security Resolution 2240 (2015). The resolution authorizes member states of the UN, for a period of 1 year, in accordance with the international law, to inspect on the high seas off the coast of Libya any vessels that they have reasonable grounds to believe had been, were being, or imminently would be used by organized criminal enterprises for migrant smuggling or human trafficking from Libya, including inflatable boats, rafts and dinghies.

As evidenced by several of the articles in Volume 15 of the Journal, there is a critical need to fully consider these and other "human element" issues on board ships or fishing vessels, not only because of essential social and economic rights concerns but also due to the impact on the achievement of other goals. In this respect, I am also pleased to announce that a Volume of the WMU Journal will be dedicated to the social dimension of shipping. We therefore wish to invite you to contribute to this Volume. 